\title{
Actors, Resources and Action Strategy: Study on the Development Dilemma of College Maker Spaces in Policy Network of Students Innovative Entrepreneurship
}

\author{
Taking Guangzhou as an Example*
}

\author{
Tao Li \\ School of Public Administration \\ South China Normal University \\ Guangzhou, China 510006
}

\begin{abstract}
Colleges have become the main body of the construction of maker spaces, which is an important participant in the implementation of the innovative entrepreneurship policy of college students. It is found that sound development of maker spaces in colleges is influenced by the choice of interests of each actor in the policy network of innovative entrepreneurship through observation and interview on the work of maker spaces in the universities in Guangzhou. There are differences in the distribution of different action body resources that have their own action strategy for the development of public space, so the strategies they adopt will affect the policy results.
\end{abstract}

Keywords-policy on college students innovative entrepreneurship; college maker spaces; policy network

\section{INTRODUCTION}

Under the new normal of economy, innovation-driven development is particularly important. Prime Minister Li Keqiang also mentioned the importance of innovationdriven development in a variety of occasions. He proposed "maker space" in the 2014 Summer Davos Forum for the first time, followed by "on the instruction of developing maker spaces to promote public innovative entrepreneurship" and other related planning and deployment work issued by the State Council. A number of maker spaces firstly emerged in Beijing, Shanghai, Shenzhen, Hangzhou, and colleges have also become an important basis for the development of maker space. The maker spaces deriving from the college activities base attract the attention of makers and entrepreneurs such as Tsinghua lab, the Zhong Da Capital. Guangdong, as a pioneer in reform and opening up, enjoys a unique geographical location. Boasting the largest number of

*Fund project: This research is the phased objective of school level project of cultivating "golden seed" --"study on current situation of college maker spaces from the perspective of policy instrument- taking Guangzhou as an example" of South China normal university in 2017-2018. Project number: 2017574 college entrepreneurs up to $39.42 \%$ in Guangdong Province, Guangzhou has a certain first-mover advantage in the entrepreneurial environment and policy design. Many colleges carry out the work of maker spaces on campus from 2015 in succession, which involving the policy behavior of government agencies from top and bottom vertically and the interest game between the various actors of maker spaces horizontally. Therefore, dynamic study on interaction and interrelation between the policy subjects of development of colleges' maker space is of great significance to comprehensively revealing the policy bottleneck of the development of maker spaces in Guangzhou and the diversification of the values of various stakeholders.

\section{POLICY NETWORK THEORY AND ITS BASIS}

Policy network theory is an analytic concept and framework formed by introducing network theory into politics and public policy, which is mainly used to analyze the interaction between subjects in policy process. Policy networks are a number of groups or organizations that are interconnected due to public interests or needs, and form a relationship of interdependence and resource sharing. Their relation is dynamic, cooperative, and mutually beneficial [1] so it can be used to explain a relationship type that actors interact with each other during policy process. Maker spaces in colleges carry out their work based on innovative entrepreneurship policy, resulting from the network formed by many interdependent subjects, so the interaction between relevant actors affects the results of policy network.

On the basis of the research practice, the author constructs the layer of main actors in the network of the development of college maker spaces horizontally: the core layer (the policy organ, presented as policy community, the intergovernmental network), the middle layer (universities, experts and college teachers, mainly in the professional network and producer network and part of the issue 
network); the outermost layer (college entrepreneurs and the media and the public, mainly turned into part of the topic network), and vertically exchanged resources, including authority, capital, legitimacy, Information and organization. According to the closeness degree of relationship between each layer of network, in which the policy community has a close relationship within the network while the topic network is in the loose side. That is, the core layer is relatively closed while the outermost one is the most open, so the distribution of resources is featured "weak outside and strong inside".

\section{STUdy OBJECT: COLLEGE MAKER SPACES}

This paper will be derived from the college activity base with college makers and entrepreneurs as the service object, and defines the service platform of innovative entrepreneurship showing the characteristics of juniorization and activation as college maker spaces. Seven colleges' maker spaces and three non-college maker spaces are selected to be researched according to the differences in developing stages and the establishing modes, and nonstructured interviews are made with the principals and makers of the maker spaces.

The maker spaces can be divided into the following categories according to the establishing mode of college maker spaces: derived from the Institute of entrepreneurship; found in the development of a school, generally in School of Economics and Management; separated from the administrative departments of the university, such as the Communist Youth League; set up by the school alumni organization; founded by school-enterprise cooperation. (As shown in "Table I")

\section{TABle I. Type of Main College MaKer Spaces in GuANGZHou}

\begin{tabular}{|c|c|c|}
\hline Type & Main features & Examples \\
\hline $\begin{array}{c}\text { Founded by } \\
\text { alumni }\end{array}$ & $\begin{array}{l}\text { Mainly founded by high } \\
\text { intelligential people based on some } \\
\text { resources of their alma mater to } \\
\text { invest in entrepreneurship of } \\
\text { schoolmates and hold culture salon. }\end{array}$ & $\begin{array}{l}\text { Entrepreneurs' } \\
\text { Club of Jinan } \\
\text { University; } \\
\text { Zhongda Venture } \\
\text { Capital }\end{array}$ \\
\hline $\begin{array}{c}\text { Founded by } \\
\text { colleges }\end{array}$ & $\begin{array}{l}\text { Provide entrepreneurship support, } \\
\text { maker space education and } \\
\text { entrepreneurial practice }\end{array}$ & $\begin{array}{l}\text { 6cit; Maker Space } \\
\text { of South China } \\
\text { Normal University }\end{array}$ \\
\hline $\begin{array}{l}\text { Founded by } \\
\text { technology } \\
\text { companies } \\
\text { of colleges }\end{array}$ & $\begin{array}{l}\text { Based on the development of } \\
\text { technology companies of colleges } \\
\text { with high technological content and } \\
\text { strong creativity, mainly develop IT } \\
\text { venture for electron and information }\end{array}$ & $\begin{array}{l}\text { Qidi Maker Space } \\
\text { of Guangzhou }\end{array}$ \\
\hline $\begin{array}{l}\text { Cooperation } \\
\text { between } \\
\text { colleges and } \\
\text { companies }\end{array}$ & $\begin{array}{l}\text { Generally colleges and companies } \\
\text { have their division of labor. } \\
\text { Colleges provide infrastructure and } \\
\text { sites while companies provide } \\
\text { practical opportunity and } \\
\text { entrepreneurship training }\end{array}$ & $\begin{array}{l}\text { Maker space of } \\
\text { Guangdong Food } \\
\text { and } \\
\text { Vocational } \\
\text { College; Prug } \\
\text { Park of South } \\
\text { China Agriculture } \\
\text { University }\end{array}$ \\
\hline
\end{tabular}

a. Organized according to the investigation materials.

What must be emphasized here is that not all the colleges that develop innovative entrepreneurship education can build a maker space. Whether the maker space can be set up, the public can operate soundly and obtain economic benefit result in the process of resource dealing and interest game for the colleges. The choices, plan, lobbying, pressing made by each actor according to their own position and grasped resources also have a close alliance.

\section{ANALYSIS ON THE POLICY NETWORK OF CURRENT DEVElOPING SituATION OF MAKER SPACES IN GUANGZHOU}

\section{Analysis of Actors in Policy Networks}

Development of the maker space construction is a development process of historical change. Maker culture rooted in the garage culture of United States gets popular around the world since 2011. In 2014, "maker" is written in the report on the work of government. Hereafter, education of creative and innovative entrepreneurship around the form of maker has gradually become a hot topic in the field of education [2]. Various forms of business incubation base, Innovation Park and so on occurred in the college campus. College maker spaces developed based on the relevant policies of government, support of college institution, and the practice of diversified needs of students innovative entrepreneurship. The interaction between the network actors related to the development of the public space has a certain influence on the formulation and implementation of the policies on innovative entrepreneurship of college students, and it profoundly influences the change of policy in the process of mutual disputes between multi-interests. All action participants have their own goals and interests, and each participant cannot completely control over the strategic actions of other participants.

\section{Analysis on the Resources of Actors in Policy Network}

According to the view of Rhodes (Rhodes, 1981) from the school of benefit coordinating, the policy network resources can be divided into five types including authority, fund, legality, information and organization. Development of any organization must rely on the resources of other organizations; in order to achieve the objectives of the organization, transaction of resources will come into being, and strong influence, certain influence, alliance and other relations will be formed among various actors.

Authority is the power to determine the policy direction or authorize other organizations and groups, which is usually the resource of government agencies (especially the central government). The coercive authority of the construction of college maker spaces is based on the policies and regulations of central and local governments and various functional departments. In regard to funding, expenditure and appropriation is undoubtedly an important resource for the actors in the policy network. Construction of college maker space depends on the series of policy document of college innovative entrepreneurship. The central government, education office, local government and education bureau, as well as schools, banks and investors are the actors who have the funds, and college students are targets of aid. Legality refers to the legitimacy and morality of government to rule and use the mandatory power [3]. At the same time, broadly, it can also be explained to be whether the organization can influence the people's wishes 
within the scope to a certain degree on behalf of policy. In the policy network of college maker spaces, all the actors have legitimacy in a certain range of vision. The information resource includes the needs and use of information of various subjects under the policy network. In general, asymmetric information will appear during the development process of any organization. Government and business will hold the information of college students' innovative entrepreneurship in the whole and development plan of the local education field, such as five-year education planning, urban planning, policy changes information; they can organize personnel, technology, venues, land, hardware facilities and equipment. In the policy network, government not only has obvious advantages, but also is an important responsibility main body [4]. As the leader of "innovative entrepreneurship", the State Council and the Bureau of Scientific Innovation, have the legitimacy and coercive force on the policy content and resources of policy implementation (power and capital) and so on, so the construction of entire college maker space should rely on the policy guidance of our country, i.e. the so-called "according to the will of central government."

\section{Action Strategies of Actors in Policy Networks}

Action strategies of the core layer

The core layer mainly refers to government agencies, including administrative department and people of political parties in central and local governments at all levels, the Ministry of Education, and Education Department and so on. The government has introduced a number of policy frameworks in succession, and uses their own resources to reduce the threshold and cost of entrepreneurship, improve subsidies and expand the scope of the supported object and enhance the ability of public entrepreneurship services. The central government vigorously advocates the construction of maker space in the design of top layer, proposes the full use of the resources advantages of colleges, and establishes an innovation base combining production and research; local government and its departments actively cooperate with national policies to promote the mission of construction of maker spaces step by step. Overall, the change of government towards innovative entrepreneurship of college students is reflected in the simplification of commercial registration, the increase of the number of supporting projects and resource allocation and the flexibility of the management on students. In general, attitudes of government departments of all levels towards innovative entrepreneurship of college students are supportive and they take positive action. Since the core layer takes overall control of the situation and masters advantages of numerous resources of the development of maker space, maker space within the college has a strong dependency on the "behaviors" of the core layer.

\section{Action strategies of the middle layer}

The middle layer is mainly made up of colleges, experts and scholars and teachers from colleges. They are the middle link between maker space and government policy. A large part of the impetus behind the development of college maker space and the pressure on the government are from the fight of middle link for the cooperation and support of government. Based on the need of constructing "innovative" school, colleges have the motivation to carry out the work related to innovative entrepreneurship of college students. At present, innovative entrepreneurship work of each campus has become an important brand of colleges, as well as an important basis for evaluation of students' practical ability. Maker space is striving for the preference of the schools or the country's to fight for support from the country, Education Bureau and schools; striving for the public opinion to form a strong pressure on the government and the school. Colleges as the "experimental" site of the maker space, are promoting innovative entrepreneurship education system step by step in line with the requirements of national policy, but some of them don't have enough strength and resources; view from experts and scholars towards maker space can be divided into two opposite tendencies-pros and cons, and thus different alliances form.

\section{The outermost layer}

Tendencies of business behavior: seeking government cooperation and support; seeking expert demonstration and support; support mentors' counseling for entrepreneurship of students; make use of various occasions to respond to the opposite part. Successful entrepreneurs will attend the entrepreneurship education lectures in colleges, or become entrepreneurial mentors of school, who can not only earn reputation, but also play the role of investors to explore excellent business projects in colleges; college students hope to get more professional and practical knowledge and skills through the support from entrepreneurial education and platform of maker space and realize their creative practice and entrepreneurial dream initially. In this process, media institutions mainly play the role of guiding public opinion by reporting the implementation model of maker spaces in various colleges; the colleges themselves will also develop self-media, such as WeChat public number, news notice of the official website to further enhance the selfinfluence and public awareness of maker space, so as to obtain the attention from government.

\section{The Contradiction and Dilemma of the Actors in the Policy Network}

The core layer and middle one: "vain efforts" and "selective perfunctoriness"

The conflict between the core layer and the middle layer is mainly the conflict between the interests of the colleges and government departments, which appear as the "vain efforts" of government policy and "selective perfunctoriness" of the colleges. It is known that the government has a greater impetus to carry out the work of the construction of maker space, and has been in a leading position in the whole policy network with absolute control over policy resources. From 2008 to the end of 2016, Guangdong Province has promulgated a total of over 100 innovative entrepreneurship policies successively, but there are only $15 \%$ of them for college innovative entrepreneurship work. Implementation of the work of college can only obtain limited resources, especially small and medium enterprises in the market that don't not have the 
advantage of market competition originally. In addition, because colleges undertake the function of education, they have a certain public welfare, with the purpose of cultivating the all-round talents required by process of national, social and economic development. However, requirement of government for innovative entrepreneurial functions in the development of maker space is actually a transfer of economic functions. How can this kind of economy and the educational function of colleges achieve balance between the development of college students innovative entrepreneurship education and market demand in contradictory operation is an urgent problem to be solved. At present, the main government departments that colleges contact with on entrepreneurship work includes scientific and technological information departments, Communist Youth League, Education Bureau, etc.; The common situation is that the school acts according to the activities and orders of various government departments without systematic thinking and preparation for the necessity or feasibility of development of maker spaces. When the resources and conditions of self-development conflicts with government orders, they can only choose "selective perfunctoriness", thus the implementation of policy becomes an "empty talk".

The middle layer and the outermost layer: the conflict between marketization and state-owned system

Most of the maker spaces of colleges are registered in the administrative departments of public institutions, which commonly have formalism and "bureaucratic atmosphere", and empty shelling; formalism refers to some leading departments and leaders lacking comprehensive knowledge of maker space. Some of them simply consider it as the title for students to carry out business education, or in response to the "Innovative Entrepreneurship University", instead of having a clear positioning for advantages and characteristics of development of maker spaces in respective schools. There is serious formalism in the cognition of leaders, their understanding towards this policy and the country's expectations; "bureaucratic" refers to the lack of autonomy of maker spaces in organization and operation. The degree of development is proportional to degree of recognition of colleges. Whether it can run well does not rely on the incubation of maker space and the number of achieved entrepreneurship, but the attitude of school leaders towards the maker space; "empty-shelling" means currently most maker spaces rush to response to the policy altogether, resulting in little value in model management, efficiency and incubation. The idea of maker space is good, but the specific implementation and operation process are unsatisfactory. Maker space operates in the market mechanism to provide places and equipment, solve the issues of high practical costs of tools and resources and difficulties financing that individual entrepreneur may face during entrepreneurship in a sharing way. The purpose is to stimulate the innovation and entrepreneurial motivation of "grassroots" entrepreneurial subjects, and then transform it into market efficiency. However, the nationalization of the college system and the public ownership of capital make maker spaces supportive in the development. It is difficult to measure the benefits of maker spaces in colleges and universities, and it cannot be just quantified.

\section{The outermost layer and the core layer: connection path divorces}

There is plight of the self-arising of development of maker spaces and the breadth of government's support. As the practitioners of national employment policy reform, colleges are the cradle of the backbone of the future society, and act as a buffer platform outputting talents to the society. One of the functions is to test whether the intelligence of talents who are cultivating for the sustainable development of the country can adapt to social demand. Implementation of the concept of "innovative entrepreneurship" the just solve the contradiction of talent supply and increase the integrating degree of higher education and social reality [5]. But the "broad irrigation" dividend policy doesn't get much effect on incentive of innovative entrepreneurship of colleges and college students. The particularity of college students as entrepreneurial subjects and the demand of entrepreneurs in the market are not treated differently in the policy. The construction of public space in colleges is a kind of market behavior, which can realize economic purpose i.e. gain profit on the premise of pursuing public welfare. The operation purpose of maker spaces as service for college students has the dual function of public welfare and economy. How to achieve equilibrium between the two is originally contradictory. The government policy has been improving and systematizing gradually, but the demand for preference of students to policy is not timely. The government understands of the entrepreneurial entity and the expectation of the school's towards the policy is out of line.

\section{CONCLUSION}

From the perspective of policy network, the development of maker spaces construction in colleges involves the action strategy, transaction and conflict of actors at different layers. To strengthen the sound development of maker space in colleges, it is necessary to construct an ecological policy network from a broader perspective and rationalize the process of resource allocation, distribution and coordination so that the actors at all layers can achieve the unity of values and beliefs. The construction of maker spaces can't accomplish overnight, colleges have both advantages and disadvantages in the development. The shortcomings in the development can't be ignored while the government should gradually change from the almighty subject, technical bureaucratic centralized management to decentralization management. It is undeniable that the policy community plays a leading role in the development of maker space in colleges. The action effect of issue network is small since it holds limited resources. The core layer is the key to the promotion of a policy. We also see Guangdong Province attaches great importance to innovative entrepreneurship related work. But with the diversity and independence of main government policy, it is emphasized that various subjects the mutually 
influence and compromise in the process of governance and policy based on equal consultation to form a consensus of solving problems, and then achieve the policy objectives [6] Maker spaces in colleges should be given more autonomy to enjoy decision-making capacity in the development in the market, rather than being imprisoned in the "chains" of institutional system, otherwise the real intention of innovative entrepreneurship will be lost.

\section{REFERENCES}

[1] Zhu Chunkui, Shen Ping, "Actors, resources and action strategy: analysis on policy network of development of hydropower in $\mathrm{Nu}$ River," Public Administration Review, vol. 4, pp. 25-46, 2010.

[2] Liu Zhiying, Xu Yi et al, "Maker space-- From 'fancy idea' to 'perfect product'," China Machine Press, 2015

[3] Yao Dazhi, "Good governance and legality," Journal of Renmin University of China, vol. 1, pp. 46-55, 2015.

[4] Shi Yanjie, "Innovation and application of policy instrument of temporary aid in our country from the perspective of government network," Journal of huang he S\&T University, vol. 5, pp. 119-128, 2016.

[5] Wang Bo, "Study on development problems and path of the concept 'innovation and entrepreneurship' in colleges," Heilongjiang Higher education Research, vol. 3, pp. 53-56, 2016.

[6] Zhu Yapeng, " The analysis perspective of policy network of study on public policy," Journalof Sun Yat-Sen University (Social Science Edition), vol. 3, pp. 80-83, 2006 